\title{
Effect of altitude and distance on zenith tropospheric delay and integrated water vapour estimations in a local GNSS CORS network
}

\author{
Omer Gokdas ${ }^{1 *}$ (iD), Mustafa Tevfik Ozludemir² (D) \\ ${ }^{1}$ Istanbul Water and Sewerage Administration, Surveying Department, Istanbul, Turkey. \\ ${ }^{2}$ Istanbul Technical University, Campus of Ayazaga, Faculty of Civil Engineering, Department of Geomatics Engineering, Sarlyer, Istanbul, Turkey.
}

\begin{abstract}
In this paper, to investigate the usability of Continuously Operating Reference Stations managed by the Istanbul Water and Sewerage Administration (ISKI CORS) for weather prediction studies, the effects of altitude and distance on Zenith Tropospheric Delay (ZTD) and Integrated Water Vapour (IWV) estimations were analysed. Within the scope of this study, the authors determined accuracies of ZTD and IWV values - based on the selected reference stations and analysed them for altitude and distance factors. GnSmart software is used for ZTD estimation as this software broadcasts CORS correction and GNSS Analysis and Positioning Software (GAPS) is used for IWV estimation. In this study, a single reference station was used to test the accuracy of ZTD and IWV values obtained from local ISKI CORS network stations (TUZL station for ZTD values and radiosonde station numbered 17064 for IWV values). The determined RMSE values could not reach the ZTD and IWV precision standards of the World Meteorology Organization (WMO). One reason for this is that a single station is selected as a reference. In short, the authors express that the ZTD and IWV values of ISKI CORS stations are not similar, but there is a significant difference between them. It was also understood that a single radiosonde station is not sufficient to determine the $I W V$ values of the stations in the local ISKI CORS network, and the GNSS IWV values obtained from the stations can be meaningful.
\end{abstract}

Keywords: GNSS, ISKI CORS, Tropospheric delay, Integrated water vapour

\section{Lokal bir GNSS CORS ağında yükseklik ve mesafenin zenit troposferik gecikme ve entegre su buharı kestirimleri üzerine etkisi}

Öz: Bu makalede, İstanbul Su ve Kanalizasyon İdaresi'nin yönettiği Uydulardan Konum Belirleme Sistemi'nin (iSKİ UKBS) hava tahmin çalışmalarında kullanılabilirliğini araştırmak için yükseklik ve mesafenin Zenit Troposferik Gecikme (Zenith Tropospheric Delay, ZTD) ve Entegre Su Buharı (Integrated Water Vapour, IWV) kestirimleri üzerindeki etkisi analiz edilmiştir. Çalışma kapsamında, yazarlar seçilen referans istasyonlara göre ZTD ve IWV değerlerinin doğruluğunu belirleyip mesafe ve yükseklik faktörlerine göre analiz etmişlerdir. ZTD kestirimi için CORS düzeltme yayını yapan GnSmart yazılımı, IWV kestirimi için ise GNSS Analiz ve Konum Belirleme Servisi (GAPS) kullanılmıştır. Bu çalışmada, yerel İSKİ UKBS ă̆ı istasyonlarından elde edilen ZTD ve IWV değerlerinin doğruluğunu test etmek için tek bir referans istasyon kullanılmıştır (ZTD değerleri için TUZL istasyonu ve IWV değerleri için 17064 numaralı radyosonda istasyonu). Belirlenen RMSE değerleri Dünya Meteoroloji Örgütü'nün ZTD ve IWV presizyon standartlarına ulaşamamıştır. Bunun bir nedeni, referans olarak tek bir istasyonun seçilmesidir. Özet olarak yazarlar, ISKI UKBS istasyonlarının ZTD ve IWV değerlerinin benzer olmadığını ancak aralarında anlamlı bir fark olduğunu ifade etmektedirler. Yerel İSKİ UKBS ă̆ındaki istasyonların IWV değerlerinin belirlenmesi için tek bir radyosonda istasyonunun yeterli olmadı $\breve{g}$, istasyonlardan elde edilen GNSS IWV değerlerinin anlamlı olabileceği de anlaşılmıştır.

Anahtar Sözcükler: GNSS, İSKİ UKBS, Troposferik gecikme, Entegre su buharı 


\section{Introduction}

There is a constant lack of humidity observations in the meteorological monitoring system, and in recent years, ground-based GNSS data (Zenith Tropospheric Delay, ZTD) has been used to address this problem (URL-1). The first ZTD estimation and Integrated Water Vapour (IWV) transformation studies with GNSS observations were carried out by Duan et al. (1996) and Rocken, van Hove \& Ware (1997). When previous studies are considered, it can be seen that impacts of weather prediction by using calculated IWV values in Numerical Weather Prediction (NWP) are analysed, and systematic developments are achieved (Bock et al., 2007; Vedel \& Huang, 2004). ZTD estimation, ZTD cycle characteristic analysis and IWV calculation are completed by using more than 100 IGS stations at a global scale (Jin, Luo \& Gleason, 2009; Wang \& Zhang, 2008, 2009). Various tropospheric correction models are developed to increase the accuracy of ZTD estimations at the global scale (Li W., Yuan, Ou, Li H., \& Li Z., 2012; Zhang, Yuan, Li W., Li Y., \& Chai, 2016). Effects of different tropospheric models with 20day data on IWV estimation are investigated, and it is seen that the Vienna Mapping Function (VMF) (Boehm, Werl, \& Schuh, 2006) showed the best performance (Tunali \& Ozludemir, 2019). Contribution of different GNSS satellite systems on ZTD and IWV estimations are analysed. Importance of using GLONASS, Galileo and BeiDou satellite systems with GPS is emphasised ( $\mathrm{Li}$ et al., 2015; Lu et al., 2015, 2016; Xu et al., 2013). Studies were conducted on the ZTD estimation performances of different software and GNSS online services. In these services, the usability of APPS, CSRS-PPP and MAGIC GNSS Online Services on ZTD and IWV estimations are showed (Ahmed et al., 2016; Astudillo, Lau, Tang, \& Moore, 2018).

As seen in the literature review, in the last decade, there were various global scale studies to use GNSS observations for meteorological purposes. In the last few years, these studies were carried out at the local scale with the use of GNSS data in ZTD and IWV estimations (Deniz, Mekik, \& Gurbuz, 2015; Deniz \& Mekik, 2017). The studies investigated the performance of different software and GNSS services on IWV estimation at a local scale (Abdellaoui, Zaourar, \& Kahlouche, 2019; Acheampong, Fosu, Amekudzi, \& Kaas, 2017).

In this paper, the authors investigated the usability of local ISKI CORS Network in the NWP. In meteorology and climate monitoring, the usability of ZTD and IWV data obtained with GNSS was analysed. There is only one radiosonde station in Istanbul, and it only gets atmospheric data twice a day (Radiosonde no: 17064) (URL-2). On the contrary, there is a local ISKI CORS Network with eight stations and providing data per second. This increases the importance of using ISKI CORS Network data in NWP. For this purpose, ZTD and IWV estimations were made at local ISKI CORS Network in Istanbul. Change of ZTD and IWV for altitude and distance for ISKI CORS Network was analysed. For this purpose, two different studies with ISKI CORS Network stations were conducted. Within the scope of the first study, 4-year ZTD data obtained between 2012 and 2015 with GnSmart software that broadcasts NRTK correction were analysed. ZTD change and seasonal cycle differences were investigated for interstation altitude and distance differences. Secondly, GAPS, a software package using the PPP method, was used in IWV estimation (Leandro, Santos \& Langley, 2007). IWV transformation was conducted by using ZWD values obtained with GAPS and surface temperature values. 17064 no. radiosonde station was selected as a reference, RMSE values were obtained and similarly, change for altitude and distance was analysed. Usability of GAPS in ZWD and IWV estimation was investigated (URL-3).

\section{Data and Methods}

Physically, tropospheric path delay occurs due to a change in the integrated refractivity through a neutral atmosphere along a vertical line. 
tropospheric path delay $=10^{-6} \int_{s}^{\infty} N(s) d s$

Here, $s$ is altitude, $N$ is a neutral atmospheric refractivity (Bevis et al., 1992). Tropospheric path delay can be mapped to the zenith direction, yielding the ZTD using a mapping function depending on elevation angle. ZTD is also expressed as the total of Zenith Hydrostatic Delay (ZHD) and Zenith Wet Delay (ZWD) (Davis, Herring, Shapiro, Rogers, \& Elgered, 1985).

$\mathrm{ZTD}=\mathrm{ZWD}+\mathrm{ZHD}$

ZHD can be calculated with surface pressure data by using tropospheric models. One of the models used in obtaining the ZHD is Saastamoinen (1972) model.

$\mathrm{ZHD}=\frac{0.0022768 \times P}{1-0.00266 \times \cos (2 \varphi)-0.00000028 \times h}$

Where $\varphi$ is the geodetic latitude of the station, $h$ is the orthometric height of the station (in meters), $P$ is the surface pressure (in mbar). ZTD and ZHD variables are used for calculating ZWD. Transformation of ZWD to IWV can be calculated with a weighted mean temperature of the atmosphere, liquid water, water vapour and atmospheric refractivity constants (Bevis et al., 1992). The main parameter in this formulation is the weighted mean temperature $\left(T_{m}\right)$ value of the troposphere in the zenith direction of the station. This parameter can be calculated by analysis of long-term radiosonde observations (Mekik \& Deniz, 2017). The derivation of the $T_{m}$ value is given by Equation 4.

$$
T_{m}=\frac{\int_{H_{S}}^{H} \frac{e}{T} d h}{\int_{H_{S}}^{H} \frac{e}{T^{2}} d h}
$$

Where $H_{S}$ is the initial height of the radiosonde observation, $H$ is the final height of the radiosonde observation, $e$ is the partial water vapour pressure in mb, $T$ is the temperature in $\mathrm{K}$, and $d h$ is the height element (Bevis et al., 1992).

Istanbul with ISKI CORS Network and one radiosonde station was chosen as the study area. Figure 1 shows the geometric distribution of ISKI CORS Network stations and radiosonde station. Latitude, longitude and altitude values are shown in Table 1 (URL-4).

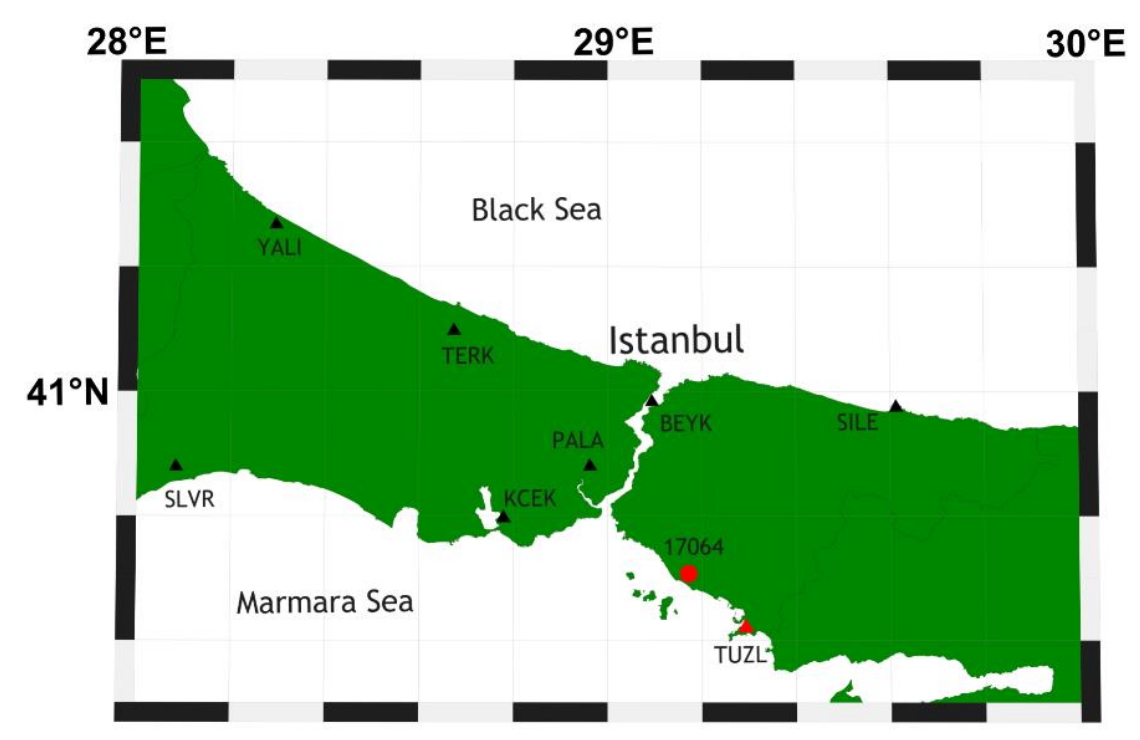

Figure 1: 8 stations linked to ISKI CORS Network and 17064 no. radiosonde station 
Table 1: Latitude, longitude and altitude (in GRS 80 ellipsoid) of 8 stations linked to ISKI CORS Network and 17064 no. radiosonde station

\begin{tabular}{cccc}
\hline Stations & Latitude & Longitude & Ellipsoidal Height (m) \\
\hline BEYK & $41^{\circ} 10^{\prime} 36.1935^{\prime \prime}$ & $29^{\circ} 05^{\prime} 36.6750^{\prime \prime}$ & 101.27 \\
\hline KCEK & $41^{\circ} 00^{\prime} 09.8993^{\prime \prime}$ & $28^{\circ} 46^{\prime} 47.1039^{\prime \prime}$ & 122.92 \\
\hline SLVR & $41^{\circ} 04^{\prime} 48.7763^{\prime \prime}$ & $28^{\circ} 05^{\prime} 00.2443^{\prime \prime}$ & 138.25 \\
\hline TERK & $41^{\circ} 18^{\prime} 11.0522^{\prime \prime}$ & $28^{\circ} 40^{\prime} 24.8789^{\prime \prime}$ & 48.01 \\
\hline TUZL & $40^{\circ} 49^{\prime} 35.3863^{\prime \prime}$ & $29^{\circ} 17^{\prime} 32.8188^{\prime \prime}$ & 55.28 \\
\hline SILE & $41^{\circ} 10^{\prime} 44.3883^{\prime \prime}$ & $29^{\circ} 36^{\prime} 47.9453^{\prime \prime}$ & 79.64 \\
\hline PALA & $41^{\circ} 05^{\prime} 10.7655^{\prime \prime}$ & $28^{\circ} 57^{\prime} 47.5242^{\prime \prime}$ & 170.56 \\
\hline YALI & $41^{\circ} 28^{\prime} 24.0517^{\prime \prime}$ & $28^{\circ} 17^{\prime} 35.5072^{\prime \prime}$ & 86.71 \\
\hline 17064 & $40^{\circ} 54^{\prime} 40.0000^{\prime \prime}$ & $29^{\circ} 09^{\prime} 21.0000^{\prime \prime}$ & 53.53 \\
\hline
\end{tabular}

4-year ZTD period between 2012-2015 from 8 stations of ISKI CORS network in Istanbul was generated with 10-s periods on GnSmart software. Precise Point Positioning (PPP) method was used in the ZTD estimations. 10-s logging rate RINEX data were used. UNB3 tropospheric model and Niell mapping function were used in the analysis (Leandro, Santos \& Langley, 2006; Niell, 1996). IGS precise data were used for orbit and clock products. ZTD time series were screened to detect and remove the outliers in the GNSS ZTD data, and Moving Mean Filter (MMF) method was applied for smoothing (Smith, 2003). It was analysed whether there is a significant difference in ZTD values between ISKI CORS stations or not. For that, TUZL station with relatively low altitude value and at the outer section of the network was selected as a reference. RMSE was used as a statistical indicator. Equation 5 was used for ZTD RMSE calculation, and correlations for altitude and distance difference were investigated.

$R M S E_{\mathrm{ZTD}}=\sqrt{\frac{\sum_{i=1}^{n}\left(\mathrm{ZTD}_{\text {estimate }}-\mathrm{ZTD}_{\text {TUZL }}\right)^{2}}{n}}$

Secondly, ZTD, ZWD, ZHD values for 19 days in June 2018 from 6 stations linked to ISKI CORS network were obtained with 30-s periods with GAPS GNSS online process. Since the temperature values of the two stations were not available, the study was conducted with 6 stations. For this purpose, the 30-s logging rate RINEX data, VMF1 predecessor tropospheric model for GAPS analysis and IGS final orbit and clock products were used. The output of ZWD values in GAPS is given by subtracting the ZHD values obtained with the model from the ZTD values. Obtained ZWD values were analysed with time series, and smoothed with the MMF method. IWV transformation was applied with weighted mean atmospheric temperature function $\Pi\left(T_{m}\right)$ and ZWD values as given in Equation 6.

$\Pi\left(T_{m}\right)=\frac{10^{6}}{p_{w} R_{v}\left(\frac{k_{3}}{T_{m}}+k_{2}^{\prime}\right)} \quad, \quad \mathrm{IWV}=\Pi\left(T_{m}\right) \cdot \mathrm{ZWD}$

Here, $T_{m} \approx 70.2+0.72 T_{s} . T_{s}$ is surface temperature. The unit of $T_{m}$ and $T_{s}$ is $\mathrm{K} . \Pi\left(T_{m}\right)$ changes as the function of the weighted mean atmospheric temperature, $p_{w}$ represents liquid water density $\left(999.97 \mathrm{kgm}^{-3}\right), R_{v}$ represents water vapour gas constant $\left(461.51 \mathrm{JK}^{-1} \mathrm{~kg}^{-1}\right), k_{3}$ ve $k_{2}^{\prime}$ represent atmospheric refractivity constants $\left(k_{3}=377600 \mp 400 \mathrm{~K}^{2} \mathrm{hpa}^{-1}\right.$ and $k_{2}^{\prime}=22.1$ $\left.\mp 2.2 \mathrm{Khpa}^{-1}\right)($ Bevis et al., 1992).

IWV values of 17064 radiosonde station were accepted as true values and IWV RMSE values of 6 stations in ISKI CORS Network were calculated with Equation 7 (URL-2). Additionally, correlation coefficients of IWV values estimated with six stations were calculated. These values were examined for altitude and distance. 
$R M S E_{\mathrm{IWV}}=\sqrt{\frac{\sum_{i=1}^{n}\left(\mathrm{IWV}_{\text {estimate }}-\mathrm{IWV}_{\text {radiosonde }}\right)^{2}}{n}}$

\section{Results and Discussion}

\subsection{Zenith Tropospheric Delay}

As explained in the previous section, ZTD change for stations in ISKI CORS Network was investigated. The effects of altitude and distance were analysed. 4-year ZTD value between 2012 and 2015 was obtained with GnSmart for 8 ISKI CORS Network stations. Obtained ZTD values were smoothed with MMF method. Figure 2 shows ZTD values, smooth ZTD values and the absolute value of residual values for the referenced TUZL station. Figure 3 shows ZTD values for all stations.

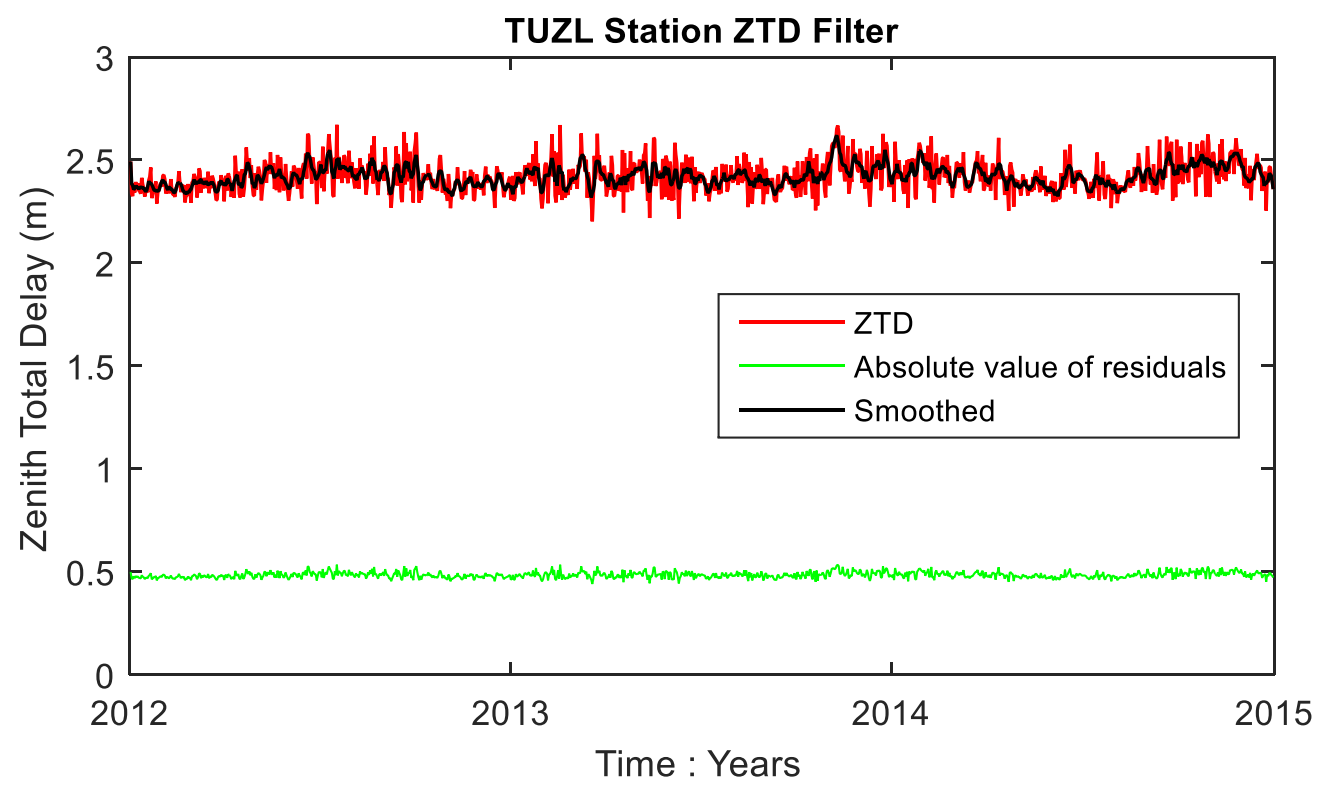

Figure 2: TUZL station ZTD Filter graphic

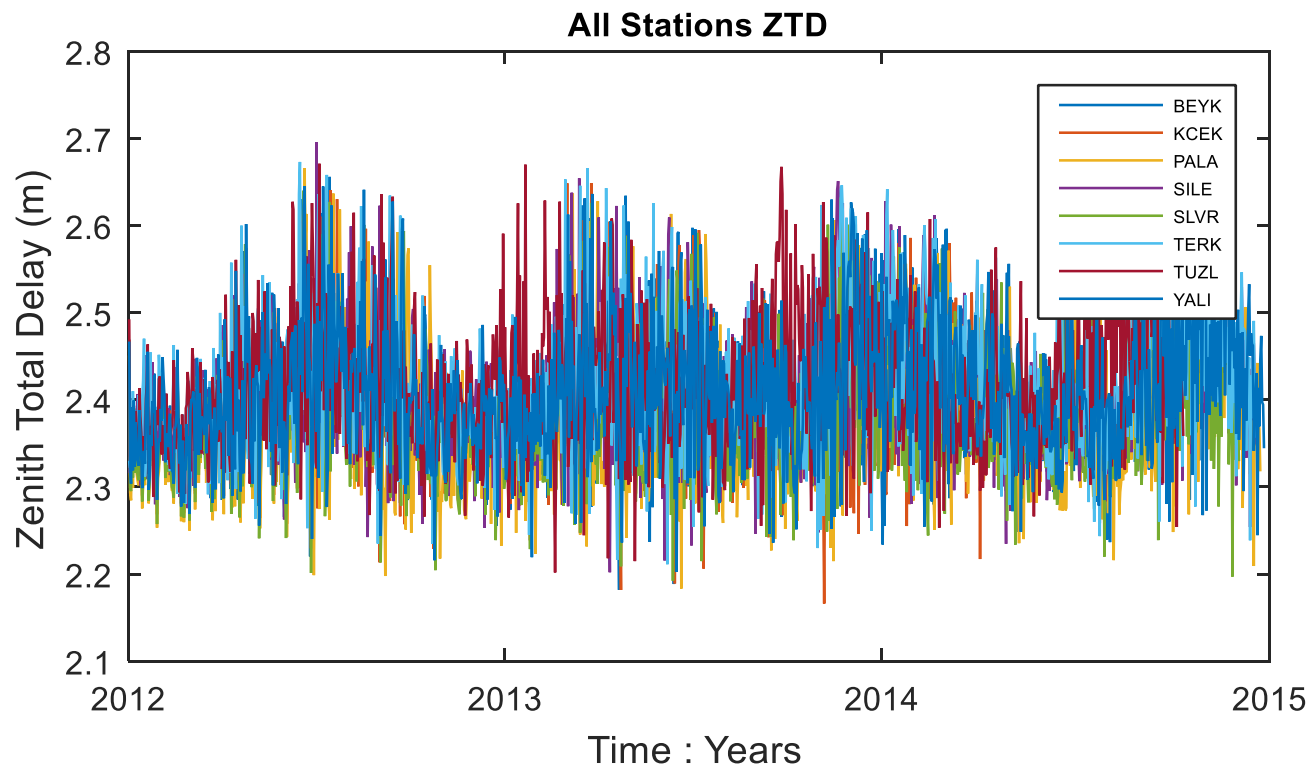

Figure 3: 4-year (2012-2015) ZTD change graphic for 8 stations 
Values in Table 2 were calculated by selecting TUZL station with relatively low altitude and at the outer part of the network as reference. Distance, altitude difference, ZTD RMSE and mean bias values of 7 stations in ISKI CORS Network are shown.

Table 2: Altitude difference, distance difference, ZTD RMSE and mean ZTD bias values

\begin{tabular}{ccccc}
\hline Station & $\Delta$ Distance $\mathbf{( k m )}$ & $\Delta$ Height $(\mathbf{m})$ & RMSE $(\mathbf{c m})$ & Mean Bias $(\mathbf{c m})$ \\
\hline PALA & 40.0 & 115.3 & \pm 3.92 & 3.75 \\
\hline KCEK & 47.0 & 67.6 & \pm 2.61 & 2.28 \\
\hline TERK & 75.0 & 7.3 & \pm 1.67 & -0.22 \\
\hline BEYK & 42.4 & 46.0 & \pm 2.03 & 1.46 \\
\hline SILE & 47.0 & 24.4 & \pm 1.37 & 0.91 \\
\hline SLVR & 105.0 & 83.0 & \pm 3.40 & 2.85 \\
\hline YALI & 111.0 & 31.4 & \pm 2.27 & 0.97 \\
\hline
\end{tabular}

When the values in Table 2 were investigated, it can be seen that ZTD values change for stations with different altitude and distance. By using the values in Table 2, ZTD - altitude difference correlation coefficient was calculated as 0.95 and ZTD distance difference correlation coefficient was calculated as 0.07. It was seen that ZTD differences for ISKI CORS Network as a local network were significant for altitude.

4-year mean ZTD values were calculated for each station, and seasonal changes were investigated. ZTD model was formed by applying the 4th order polynomial function on ZTD change graphic (Figure 4).
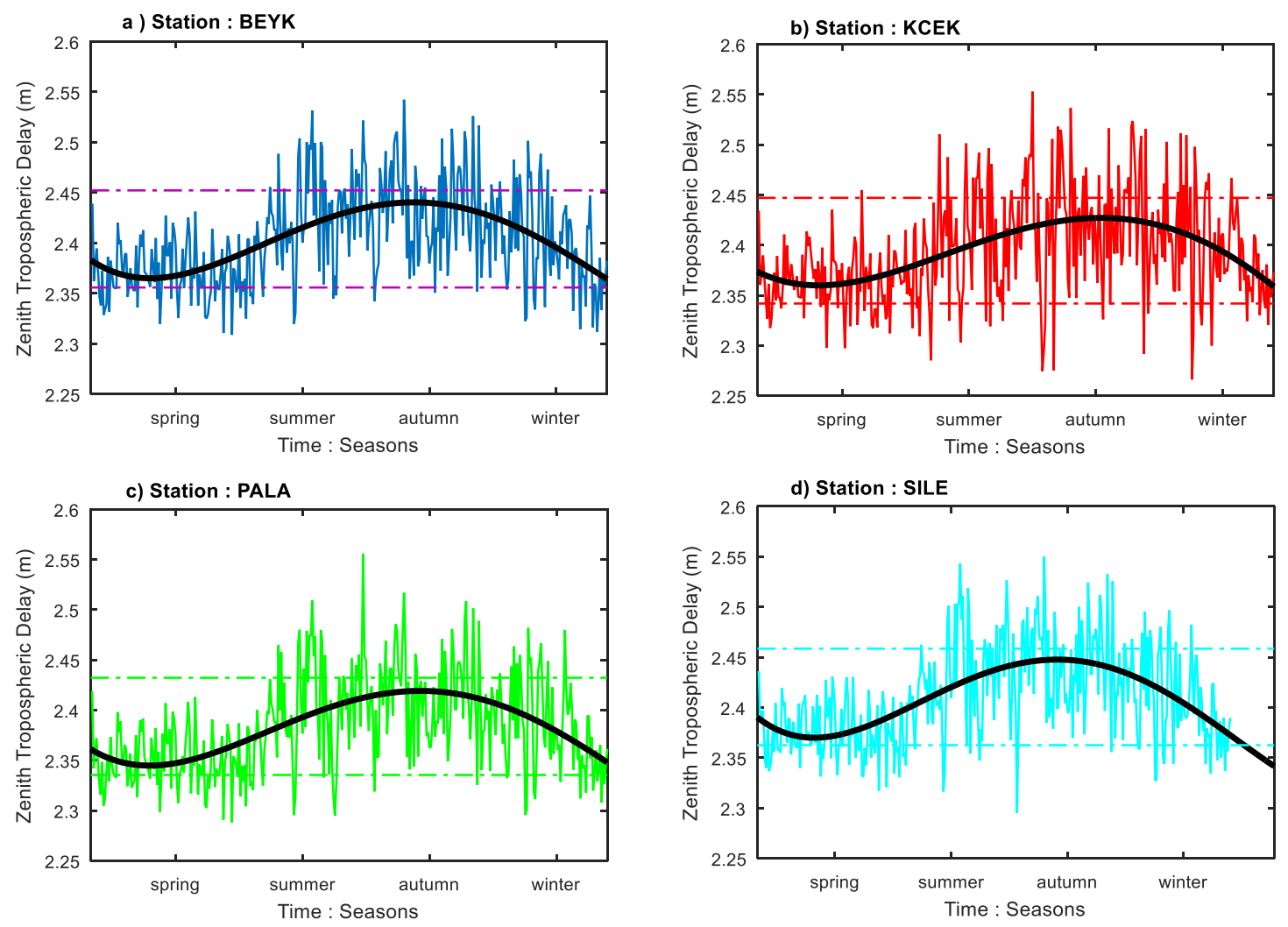

Figure 4.1: Seasonal change of 8 stations linked in ISKI CORS Network (Black line shows the polynomial function of ZTD; two horizontal lines show $1 \sigma$ range of $Z T D$ ) 

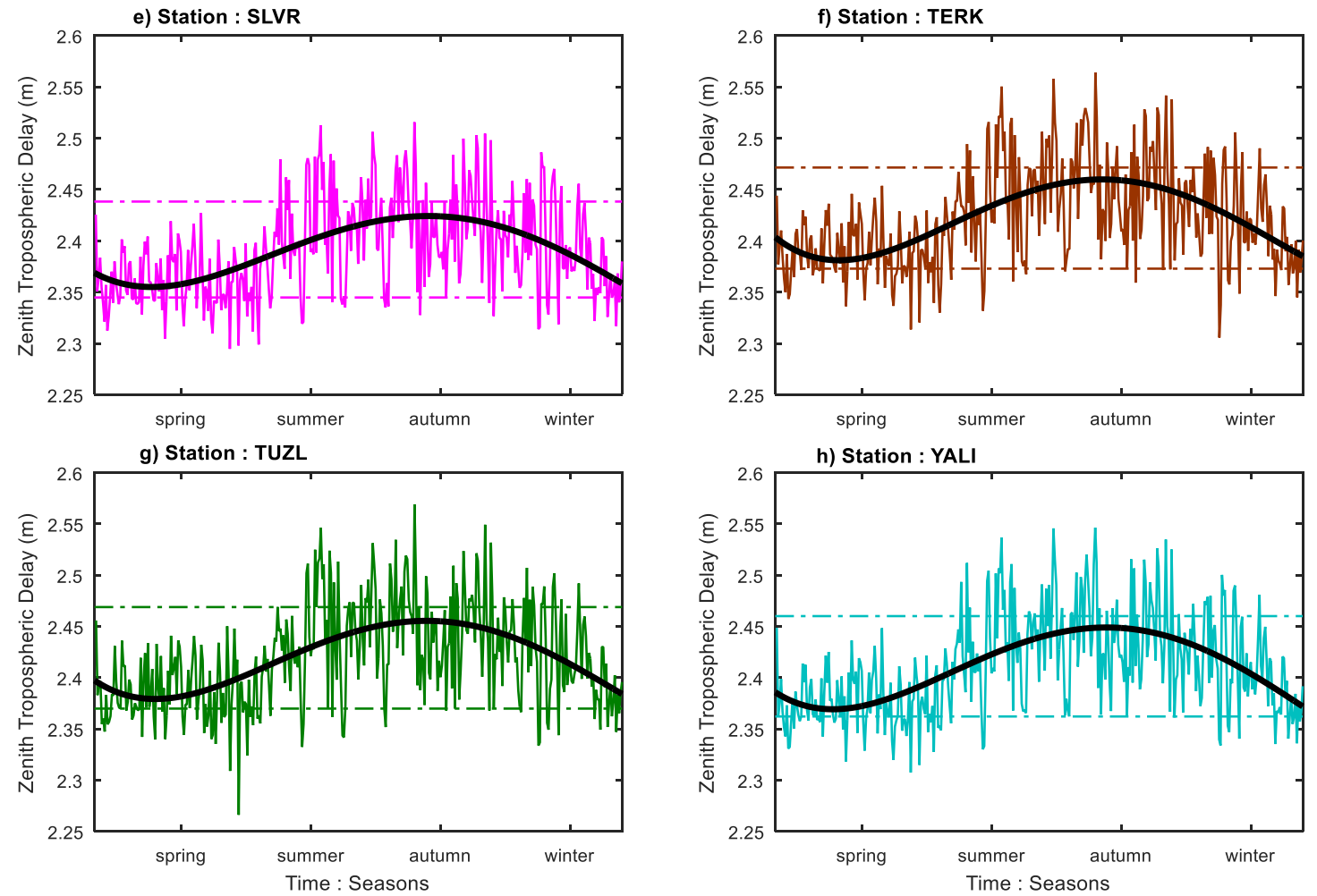

Figure 4.2: Seasonal change of 8 stations linked in ISKI CORS Network (Black line shows the polynomial function of ZTD; two horizontal lines show $1 \sigma$ range of $Z T D)$

As seen in Table 3, the mean ZTD values in a year range between $2.384 \mathrm{~m}$ and $2.422 \mathrm{~m}$ (PALA, TERK). Standard deviation values are between $\pm 4.7 \mathrm{~cm}$ and $\pm 5.3 \mathrm{~cm}$ (SLVR, KCEK).

Table 3: Annual mean, maximum ZTD, minimum ZTD and std. values for 8 stations

\begin{tabular}{ccccc}
\hline Stations & Mean ZTD $(\mathbf{m})$ & Max. ZTD $(\mathbf{m})$ & Min. ZTD $(\mathbf{m})$ & Std. $(\mathbf{c m})$ \\
\hline BEYK & 2.404 & 2.542 & 2.309 & \pm 4.8 \\
\hline KCEK & 2.395 & 2.553 & 2.266 & \pm 5.3 \\
\hline SLVR & 2.392 & 2.516 & 2.295 & \pm 4.7 \\
\hline TERK & 2.422 & 2.564 & 2.306 & \pm 4.9 \\
\hline TUZL & 2.419 & 2.561 & 2.266 & \pm 5.0 \\
\hline SILE & 2.411 & 2.551 & 2.295 & \pm 4.8 \\
\hline YALI & 2.411 & 2.547 & 2.308 & \pm 4.9 \\
\hline PALA & 2.384 & 2.586 & 2.288 & \pm 4.8 \\
\hline
\end{tabular}

Seasonal ZTD values for eight stations were investigated, and the mean seasonal change was calculated. Polynomial function model was formed (Figure 5a). Model residual values are shown in Figure 5b.
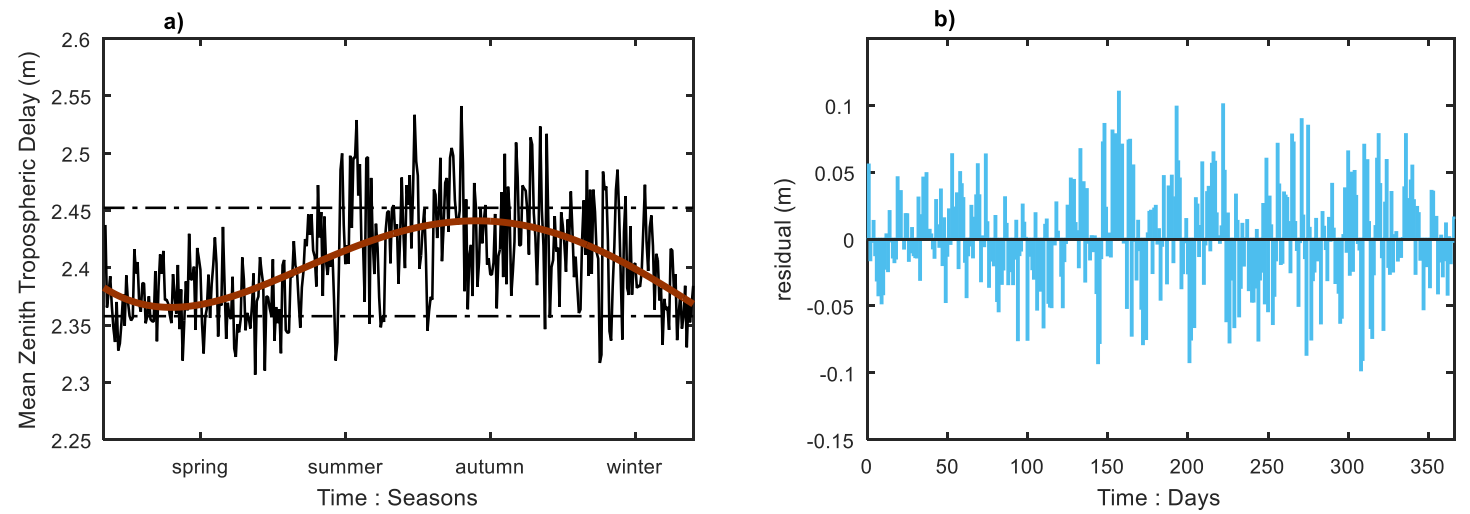

Figure 5: Mean seasonal change of 8 stations (Figure 5a has the polynomial model, Figure $5 \mathrm{~b}$ has the residual values of the model) 
Mean ZTD, maximum ZTD, minimum ZTD and standard deviation values for Figure 5a are shown in Table 4. Accordingly, autumn and summer ZTD values (Mean ZTD: 2.423 m, 2.437 m, respectively) for ISKI CORS Network stations were higher than spring and winter (Mean ZTD: $2.383 \mathrm{~m}, 2.378 \mathrm{~m}$, respectively). As stated in the Introduction section, ZTD consists of two components. Although $90 \%$ of the ZTD is the ZHD component, there is a correlation between ZTD and ZWD. ZWD is $90 \%$ positive correlated with temperature and $10 \%$ with relative humidity. Accordingly, the high mean temperatures of summer and autumn seasons for Istanbul increased the ZTD mean values (Jin, Park J.U., Cho, \& Park P.H., 2007). As it can be seen from Table 4, changes in ZTD were at the lowest level for winter $(\mathrm{Std} . \pm 2.9 \mathrm{~cm})$.

Table 4: Seasonal mean, maximum-minimum ZTD values and ZTD std. values for all stations

\begin{tabular}{ccccc}
\hline Seasons & Mean ZTD $(\mathbf{m})$ & Max. ZTD $(\mathbf{m})$ & Min. ZTD $(\mathbf{m})$ & Std. $(\mathbf{c m})$ \\
\hline Spring & 2.383 & 2.500 & 2.307 & \pm 3.9 \\
\hline Summer & 2.437 & 2.541 & 2.345 & \pm 4.6 \\
\hline Autumn & 2.423 & 2.523 & 2.317 & \pm 4.6 \\
\hline Winter & 2.378 & 2.472 & 2.319 & \pm 2.9 \\
\hline
\end{tabular}

\subsection{Integrated Water Vapour}

Effects of the altitude - distance difference of ISKI CORS Network stations on IWV were analysed to investigate the usability of local ISKI CORS Network for IWV estimation. For that purpose, GAPS was used on six stations and ZTD, ZWD and ZHD values were obtained for a 30-s period. ZWD values were analysed with time series and smoothed with MMF method. Figure 6 shows ZWD filter graphics for each station.
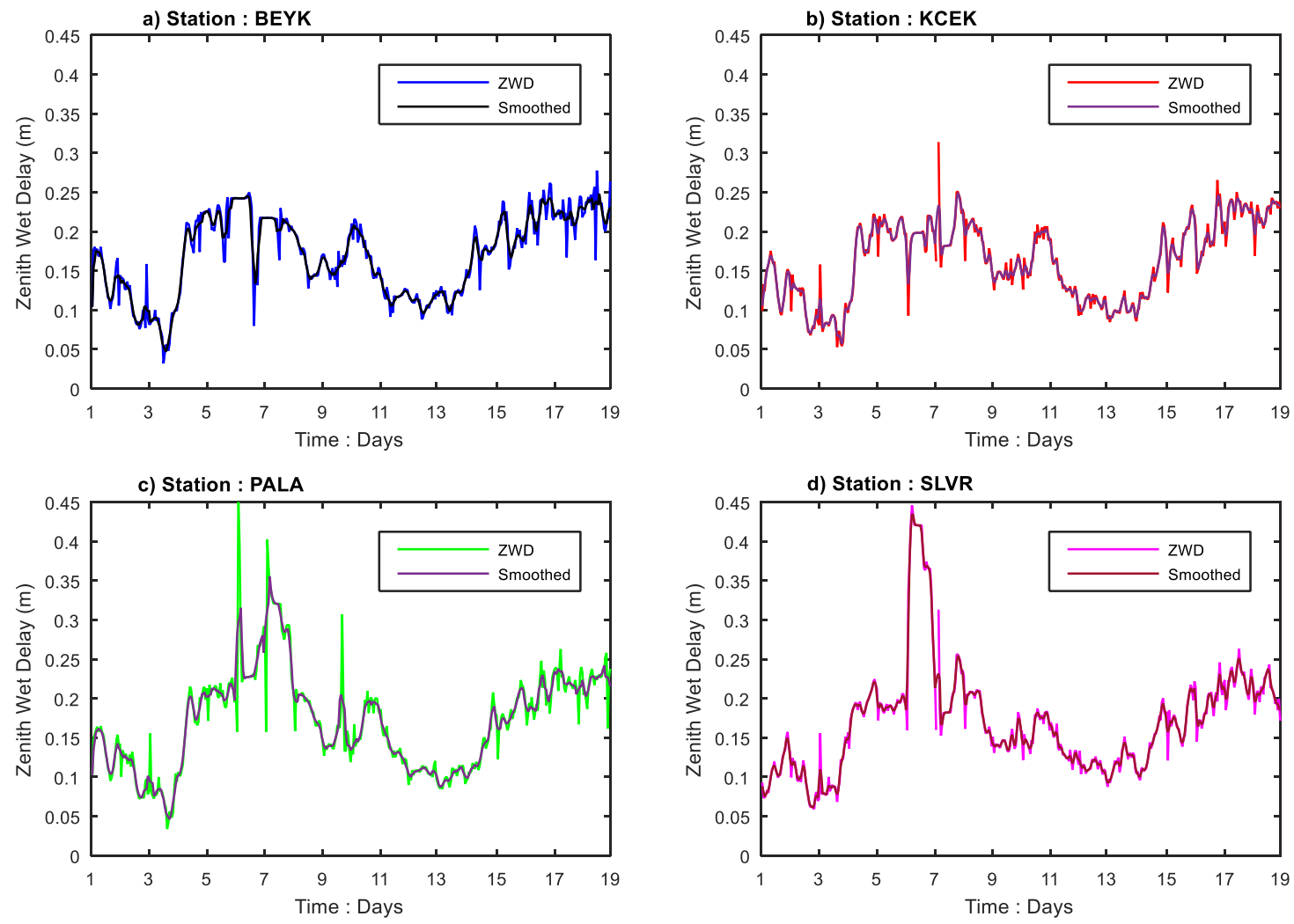

Figure 6.1: ZWD Filter change graph for 6 stations 

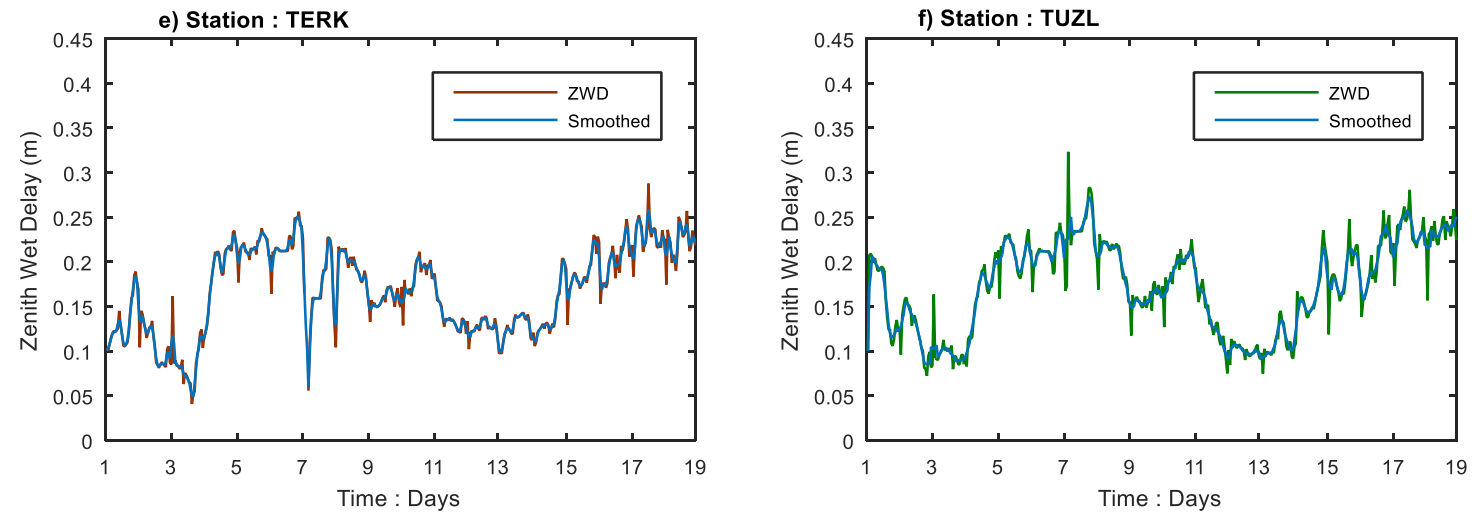

Figure 6.2: ZWD Filter change graph for 6 stations

IWV transformation was calculated using the ZWD values, mean temperature Tm value and constants in Equation 6. Obtained GNSS IWV values were compared with IWV values in radiosonde station (no: 17064) as repeated twice a day (Figure 7).
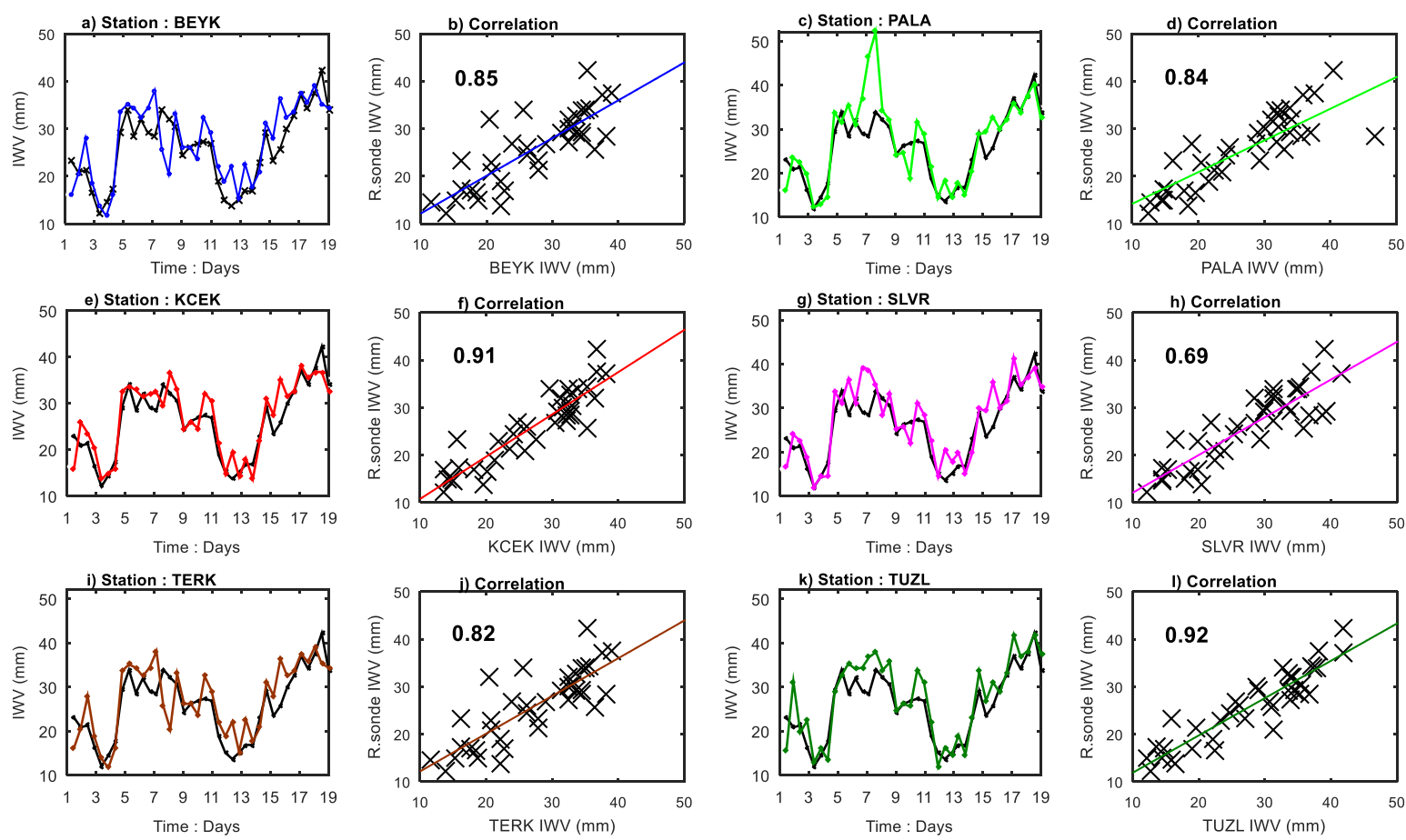

Figure 7: GNSS - Radiosonde IWV values and correlations for 6 stations (Blackline shows IWV values, others show GNSS IWV values)

Altitude and distance differences between radiosonde station and GNSS stations, IWV RMSE, mean bias values and correlation coefficients are shown in Table 5. IWV RMSE values obtained with GAPS range between $\pm 3.4 \mathrm{~mm}$ and \pm 7.6 $\mathrm{mm}$. When compared with the RMSE values between $2.22 \mathrm{~mm}$ and $5.53 \mathrm{~mm}$ obtained in the study performed with 6 stations by Abdellaoui et al. (2019), it is seen that similar results were obtained (except for SLVR station) (Table 5).

Correlation coefficients range between 0.69 and 0.92 . Similarly, when compared with 0.73 and 0.87 correlation coefficients in a single station local study conducted by Acheampong et al. (2017) with APPS and CSRS-PPP online service, it was seen that correlation coefficient of SLVR station was low, and BEYK, KCEK and TUZL stations had high compliance. The PALA and TERK stations gave similar correlation result in IWV values (Table 5). According to Table 5, correlation coefficients of RMSE values with distance and altitude differences are 0.81 and 0.42 . Accordingly, it could be said that the distance difference for GNSS IWV values has a higher effect than altitude differences, and there are significant differences between IWV values of ISKI CORS stations. 
Table 5: Distance and altitude difference, IWV RMSE and mean IWV bias values for 6 stations

\begin{tabular}{|c|c|c|c|c|c|}
\hline Station & $\Delta$ Distance $(\mathrm{km})$ & $\Delta$ Height (m) & RMSE (mm) & Mean Bias (mm) & Radiosonde Corr. \\
\hline PALA & 26.1 & 117.0 & \pm 5.4 & 1.6 & 0.84 \\
\hline BEYK & 31.0 & 47.7 & \pm 4.3 & 1.5 & 0.88 \\
\hline KCEK & 33.5 & 69.4 & \pm 3.4 & 1.1 & 0.91 \\
\hline TERK & 60.0 & -5.5 & \pm 4.8 & 1.4 & 0.82 \\
\hline TUZL & 14.4 & 1.8 & \pm 4.0 & 2.0 & 0.92 \\
\hline SLVR & 92.0 & 84.7 & \pm 7.6 & 1.7 & 0.69 \\
\hline
\end{tabular}

According to the standards of the World Meteorology Organization (WMO), it is stated that IWV should have a precision of approximately $\pm 1 \mathrm{~mm} / \pm 1.3 \mathrm{~mm}$. It is understood that the ZTD value must have a precision of $\pm 7 \mathrm{~mm}$ or better to achieve an IWV precision of $\pm 1 \mathrm{~mm}$ (Mekik \& Deniz, 2017). ZTD RMSE and IWV RMSE values in Tables 2 and Table 5 did not reach the specified accuracy value. One reason for this is that only one reference station (TUZL station for ZTD values, radiosonde station 17064 for IWV values) was selected. These results show that the ZTD and IWV values of ISKI CORS stations are not similar, there is a significant difference between them. Also, the effect of height and distance on IWV values was examined in the study. In this way, it has been understood that a single radiosonde station is not sufficient for stations in the local network, and the GNSS IWV values obtained from the stations may be significant.

\section{Conclusion}

In this study, the authors investigated the usability of ISKI CORS Network on ZTD and IWV estimations to contribute to weather prediction studies. Additionally, GAPS online service performance is tested for IWV estimations. In this study to analyse the altitude and distance changes of ZTD and IWV in a local network, ISKI CORS Network stations designed for Istanbul and shown in Figure 1 were used. Geometrically, the highest altitude difference is between PALA and TERK stations $(128.55 \mathrm{~m})$. The shortest distance between the stations is between BEYK and PALA (14.0 km), and the longest distance is between SILE and YALI stations $(115.0 \mathrm{~km})$. Two different studies were conducted for ZTD and IWV analysis. ZTD analysis was conducted with 4-year data of 8 stations between 2012 and 2015. GnSmart software where correction broadcast data were calculated for CORS network users was adopted. 4-year ZTD values were obtained with 10-s period (Figure 3). UNB3 tropospheric model and Niell mapping function were used in the analysis. IGS precise data were used for orbit and clock products. ZTD values were analysed with time series and smoothed with MMF method. TUZL station with relatively low altitude value and at the outer part of the network was selected as the reference, and ZTD RMSE values were calculated. ZTD RMSEs were calculated between $\pm 1.4 \mathrm{~cm}$ and $\pm 3.9 \mathrm{~cm}$, and the mean biases were calculated between $-0.2 \mathrm{~cm}$ and 3.7 $\mathrm{cm}$. It was seen that there were significant differences for ZTD values for ISKI CORS station distances and altitudes. ZTD altitude difference correlation was calculated as 0.95 and ZTD - distance correlation was calculated as 0.07. Additionally, seasonal change of ZTD values obtained from ISKI CORS Network stations was analysed. Accordingly, there was no difference between the stations for ZTD seasonal movements (Table 3). On the other hand, it was seen that ZTD and std. values during winter and spring (ZTD: $2.38 \mathrm{~m}$, std: $\pm 2.9 \mathrm{~cm} / \pm 3.9 \mathrm{~cm}$ ) were lower than summer and autumn (mean ZTD: $2.43 \mathrm{~m}$, std: $\pm 4.6 \mathrm{~cm}$ ) (Table 4). For IWV analysis as the second study, 19-day ZWD values in June 2018 from 6 stations linked to ISKI CORS Network were obtained with GAPS with 30-s periods. VMF1 tropospheric model and IGS final data were used. ZWD values were smoothed with the same method as ZTD (Figure 6), and ZWD-IWV transformation was calculated with Equation 6. These values were compared with radiosonde IWV values. IWV RMSE values and correlation coefficients were calculated for six stations (Table 5). Accordingly, IWV RMSE values were calculated as $\pm 3.4 \mathrm{~mm} / \pm 7.6$ $\mathrm{mm}$, and correlation coefficients were calculated in 0.69 - 0.92 range. The results obtained are consistent with similar studies (Abdellaoui et al., 2019; Acheampong et al., 2017). 
As a result, the authors state that there is a significant difference between the ZTD and IWV values of ISKI CORS stations. It has been understood that a single radiosonde station is not sufficient to determine the IWV values of the stations in the local ISKI CORS network. It was emphasized that the GNSS IWV values obtained from the stations could be significant.

\section{Acknowledgements}

The authors thank Istanbul Water and Sewerage Administration's Survey Department, which allowed to access to CORS software and data. The authors thank the Disaster Coordination Centre, which shared the surface meteorological data. The authors would like to acknowledge GAPS GNSS Analysis Centre's contribution to their research.

\section{Author Contribution}

Omer Gokdas: Conception, Design, Literature review, Data collection, Analysis and interpretation, Writing (original draft). Mustafa Tevfik Ozludemir: Design, Analysis and interpretation, Supervision, Writing (review and editing).

\section{References}

Abdellaoui, H., Zaourar, N., \& Kahlouche, S. (2019). Contribution of permanent stations GPS data to estimate the water vapor content over Algeria. Arabian Journal of Geosciences, $12(3), 81$.

Acheampong, A. A., Fosu, C., Amekudzi, L. K., \& Kaas, E. (2017). Precipitable water comparisons over Ghana using PPP Techniques and reanalysis data. South African Journal of Geomatics, 6(3), 449-460.

Ahmed, F., Vaclavovic, P., Teferle, F. N., Douša, J., Bingley, R., \& Laurichesse, D. (2016). Comparative analysis of real-time precise point positioning zenith total delay estimates. GPS Solutions, 20(2), 187-199.

Astudillo, J.M., Lau, L., Tang, Y. T., \& Moore, T. (2018). Analysing the zenith tropospheric delay estimates in on-line precise point positioning (PPP) services and PPP software packages. Sensors, 18(2), 580.

Bevis, M., Businger, S., Herring, T. A., Rocken, C., Anthes, R. A., \& Ware, R. H. (1992). GPS Meteorology: Remote sensing of atmospheric water vapor using or estimation of the wet delay. J. Geophys. Res, 97, 15787-15801.

Bock, O., Bouin, M. N., Walpersdorf, A., Lafore, J. P., Janicot, S., Guichard, F., \& Agusti-Panareda, A. (2007). Comparison of groundbased GPS precipitable water vapour to independent observations and NWP model reanalyses over Africa. Quarterly Journal of the Royal Meteorological Society: A journal of the atmospheric sciences, applied meteorology and physical oceanography, 133(629), 2011-2027.

Boehm, J., Werl, B., \& Schuh, H. (2006). Troposphere mapping functions for GPS and very long baseline interferometry from European Centre for Medium-Range Weather Forecasts operational analysis data. Journal of geophysical research: solid earth, 111(B2).

Davis, J. L., Herring, T. A., Shapiro, I. I., Rogers, A. E. E., \& Elgered, G. (1985). Geodesy by radio interferometry: Effects of atmospheric modeling errors on estimates of baseline length. Radio science, 20(6), 1593-1607.

Deniz, I., Mekik, C., \& Gurbuz, G. (2015). Türkiye için Islak Zenit Gecikmesi Su Buharı Dönüşüm Faktörünün Modellenmesi. UCTEA Chamber of Survey and Cadastre Engineers. 15. Turkey Scientific and Technical Conference, Ankara, Turkey.

Deniz, I., \& Mekik, C. (2017). TUSAGA-Aktif’ in GNSS Meteorolojisi Ağı Olarak Kullanılması. UCTEA Chamber of Survey and Cadastre Engineers. 16. Turkey Scientific and Technical Conference, Ankara, Turkey.

Duan, J., Bevis, M., Fang, P., Bock, Y., Chiswell, S., Businger, S., Rocken, C., Solheim, F., van Hove, T., Ware, R., McClusky, S., Herring, T.A., \& King, R.W. (1996). GPS meteorology: Direct estimation of the absolute value of precipitable water. Journal of applied meteorology, 35(6), 830-838.

Jin, S., Park, J. U., Cho, J. H., \& Park, P. H. (2007). Seasonal variability of GPS-derived zenith tropospheric delay (1994-2006) and climate implications. Journal of geophysical research: atmospheres, 112(D9). 
Jin, S., Luo, O. F., \& Gleason, S. (2009). Characterization of diurnal cycles in ZTD from a decade of global GPS observations. Journal of Geodesy, 83(6), 537-545.

Leandro, R F., Santos, M. C., \& Langley, R. B. (2006). UNB neutral atmosphere models: development and performance. Proceedings of ION NTM, 564-573.

Leandro, R. F., Santos, M. C., \& Langley, R. B. (2007). GAPS: The GPS analysis and positioning software-A brief overview. In Proceedings of the 20th International Technical Meeting of the Satellite Division of The Institute of Navigation (ION GNSS 2007), $1807-1811$.

Li, W., Yuan, Y., Ou, J., Li, H., \& Li, Z. (2012). A New Global, Zenith Tropospheric Delay IGGtrop for GNSS Applications. Chin. Sci. Bull., 57, 2132 - 2139.

Li, X., Dick, G., Lu, C., Ge, M., Nilsson, T., Ning, T., Wickert, J., \& Schuh, H. (2015). Multi-GNSS meteorology: real-time retrieving of atmospheric water vapor from BeiDou, Galileo, GLONASS, and GPS observations. IEEE Transactions on Geoscience and Remote Sensing, 53(12), 6385-6393.

Lu, C., Li, X., Nilsson, T., Ning, T., Heinkelmann, R., Ge, M., Glaser, S., \& Schuh, H. (2015). Real-time retrieval of precipitable water vapor from GPS and BeiDou observations. Journal of Geodesy, 89(9), 843-856.

Lu, C., Li, X., Ge, M., Heinkelmann, R., Nilsson, T., Soja, B., Dick, G., \& Schuh, H. (2016). Estimation and evaluation of real-time precipitable water vapor from GLONASS and GPS. GPS solutions, 20(4), 703-713.

Mekik, C., \& Deniz, I. (2017). Modelling and validation of the weighted mean temperature for Turkey. Meteorological Applications, 24(1), 92-100.

Niell, A. E. (1996). Global mapping functions for the atmosphere delay at radio wavelengths. Journal of Geophysical Research: Solid Earth, 101(B2), 3227-3246.

Rocken, C., van Hove, T., \& Ware, R. (1997). Near real-time GPS sensing of atmospheric water vapor. Geophysical research letters, 24(24), 3221-3224.

Saastamoinen, J. (1972). Atmospheric correction for the troposphere and stratosphere in radio ranging satellites. The use of artificial satellites for geodesy, 15, 247-251.

Smith, S. W. (2003). Digital Signal Processing: A Practical Guide for Engineers and Scientists. Burlington, USA: Newnes.

Tunali, E., \& Ozludemir, M. T. (2019). GNSS PPP with different troposphere models during severe weather conditions. GPS Solutions, 23(3), 82.

Vedel, H., \& Huang, X. Y. (2004). Impact of ground based GPS data on numerical weather prediction. Journal of the Meteorological Society of Japan. Ser. II, 82(1B), 459-472.

Wang, J., \& Zhang, L. (2008). Systematic errors in global radiosonde precipitable water data from comparisons with ground-based GPS measurements. Journal of Climate, 21(10), 2218-2238.

Wang, J., \& Zhang, L. (2009). Climate applications of a global, 2-hourly atmospheric precipitable water dataset derived from IGS tropospheric products. Journal of Geodesy, 83(3-4), 209-217.

Xu, A., Xu, Z., Ge, M., Xu, X., Zhu, H., \& Sui, X. (2013). Estimating zenith tropospheric delays from BeiDou navigation satellite system observations. Sensors, 13(4), 4514-4526.

Zhang, H., Yuan, Y., Li, W., Li, Y., \& Chai, Y. (2016). Assessment of three tropospheric delay models (IGGtrop, EGNOS and UNB3m) based on precise point positioning in the Chinese region. Sensors, 16(1), 122.

URL-1: WMO. https://public.wmo.int/en/resources/bulletin/global-observing-system (Accessed: 14 August 2020).

URL-2: Radiosonde. University of Wyoming, Department of Atmospheric Science. http://weather.uwyo.edu/upperair/sounding.html (Accessed: 1 July 2018).

URL-3: GAPS. GNSS Analysis and Positioning Service. http://gaps.gge.unb.ca (Accessed: 30 June 2018).

URL-4: ISKI CORS. http://ukbs.iski.gov.tr (Accessed: 1 May 2018). 